\title{
Synthesis, structural characterization and catalytic application of citrate-stabilized monometallic and bimetallic palladium@copper nanoparticles in microbial anti-activities
}

This article was published in the following Dove Press journal:

International Journal of Nanomedicine

Inayat Ullah'

Khakemin Khan ${ }^{2}$

Muhammad Sohail ${ }^{3}$

Kifayat Ullah ${ }^{4}$

Anwar Ullah ${ }^{4}$

Shabnum Shaheen ${ }^{5}$

'Lanzhou Center for Tuberculosis Research and Institute of Pathogen Biology, School of Basic Medical Sciences, Lanzhou University, Lanzhou, People's Republic of China; ${ }^{2}$ Department of Chemistry, Hazara University, Mansehra, Khyber Pakhtunkhwa, Pakistan; ${ }^{3}$ School of Chemical Engineering and the Environment, Beijing Institute of Technology, Beijing I0008I, People's Republic of China; ${ }^{4}$ Department of Biosciences, COMSATS Institute of Information Technology, Park Road, Chack Sahzad, Islamabad, Pakistan; ${ }^{5}$ Department of Botany, Lahore College for Women University, Lahore, Punjab-Pakistan

\section{Correspondence: Kifayat Ullah} Department of Biosciences, COMSATS Institute of Information Technology, Park Road, Chack Sahzad, Islamabad, Pakistan Email kifayat.dawar@comsats.edu.pk

\begin{abstract}
In this research work, copper $(\mathrm{Cu})$, palladium $(\mathrm{Pd})$ and their bimetallic palladium@ copper $(\mathrm{Pd} @ \mathrm{Cu})$ nanoparticles were synthesized using trisodium citrate as a stabilizing agent using the known chemical reduction method. The synthesized Cu, Pd and Pd@Cu nanoparticles were characterized by the ultraviolet-visible spectroscopy, scanning electron microscopy and $\mathrm{X}$-ray diffraction spectroscopy, respectively. The different volumes of trisodium citrate were used for the stability of synthesized monometallic $\mathrm{Cu}, \mathrm{Pd}$ and bimetallic $\mathrm{Pd} @ \mathrm{Cu}$ nanoparticles. The synthesized $\mathrm{Cu}, \mathrm{Pd}$ and their bimetallic $\mathrm{Pd} @ \mathrm{Cu}$ nanoparticles were used as catalysts for the reduction of 4-nitrophenol in the presence of $\mathrm{NaBH}_{4}$. The bimetallic $\mathrm{Pd} @ \mathrm{Cu}$ nanoparticles had efficient catalytic activities with a high rate constant $\left(1.812 \mathrm{~min}^{-1}\right)$ as compared to monometallic $\mathrm{Cu}\left(0.3322 \mathrm{~min}^{-1}\right)$ and $\mathrm{Pd}\left(0.2689 \mathrm{~min}^{-1}\right)$ nanoparticles, respectively. The correlation coefficient $\left(R^{2}\right)$ was found to be 0.99 for these three nanoparticles. Meanwhile, the effect of $\mathrm{Cu}$, Pd and bimetallic Pd@Cu nanoparticles was checked on the physiology of specific different micro-organism strains. The bimetallic Pd@Cu nanoparticles reported the maximum resistance at maximum level the growth of bacterial strain and had observed a smooth antibacterial graph than the monometallic analogs.
\end{abstract}

Keywords: stabilizing agent, bimetallic nanoparticles, catalytic activities, antimicrobial effects

\section{Introduction}

Nanotechnology deals with small chemical materials ranging from 1 to $100 \mathrm{~nm}$, having specific physicochemical properties that are totally different from their bulk materials. ${ }^{1-3}$ In the last few decades, nanotechnology has been gaining a tremendous reputation in the field of biotechnology, electronics, drug delivery, catalysis, and so on. ${ }^{4,5}$ Nanomaterials have size- and shape-dependent properties, which make them totally different from their bulk counterparts, while the bulk materials have size- and shape-independent properties. ${ }^{6}$ Due to the surface plasmon resonance, metal nanoparticles show different colors by changing shape and particle size. ${ }^{7}$ The nanoparticles with smaller size than the wavelength of electromagnetic radiations and having high penetrating power are efficiently used as conducting materials. ${ }^{8}$ Similarly, the melting point of this material is automatically decreased with decrease in particle size, probably up to $<10 \mathrm{~nm} .{ }^{6}$ Metal nanoparticles are very attractive because of its high mechanical strength, thermal conductivity, electrical conductivity, chemical stability and large surface area. ${ }^{9}$ Current advancements in nanomaterials have guaranteed 
that the metal nanoparticles can play an important role in the different concerned technologies. ${ }^{10-12}$

Nowadays, metal-fabricated nanomaterials have been gaining extensive interest because of their enriched optical, catalytic and antibacterial properties. ${ }^{13,14}$ Hence, it is made easier to recover and reuse the catalysts by incorporation of magnetic nanoparticles in catalysts or absorbents simply by applying the external magnetic field. ${ }^{15}$ That is why, different metal nanoparticles, particularly the gold, cobalt, nickel and silver, have been synthesized. ${ }^{16,17}$ Among these metals, gold and silver nanoparticles are much used in different fields because of their conductivity, inertness, surface plasmon resonance and bright color. ${ }^{18}$ However, the application of gold at industrial scale is restricted because of its high cost. Nevertheless, copper $(\mathrm{Cu})$ nanoparticles are extensively used because of their low cost in good electrical, thermal, catalytic and biomedical applications. ${ }^{19}$ Moreover, $\mathrm{Cu}$ nanoparticles can act as antibiotics and antimicrobial and antifungal agents particularly in the plastic, coating and textile industries. ${ }^{20,21}$ Similarly, palladium (Pd) nanoparticles have been widely studied in a wide range of catalytic applications including hydrogenations, oxidations, carbon-carbon bond formation, and electrochemical reactions in the fuel cells. ${ }^{22,23}$ However, it should be noted that the application of Pd goes beyond catalysis. For example, the property of Pd to adsorb hydrogen has also led to use of Pd-based nanoparticles in hydrogen storage and sensing applications. There are many types of environmental pollutants, Congo red, methylene blue, Rhodamine B, Rhodamine G, methyl orange, eosin $\mathrm{Y}$ and nitro compounds. ${ }^{24}$ The compounds having nitro group are selected on the basis of their utmost importance in environment and in various manufacturing industries in general, particularly in the pharmacology products, aromatic products, dyes and pigments. Mostly, in pharmaceutical sector, the antipyretic and analgesic type of medicines, that is, paracetamol and acetanilide etcare, are synthesized from the 4-aminophenol, which are produced by the catalytic activities of 4-nitrophenol (4-NP). Similarly, the aforementioned compounds were prepared by the reduction of 2 nitrophenol (2-NP) and 4-nitroaminophenol (4-NA), respectively. These compounds are mostly used as a source in industry for the production of different pigments, dyes, and so on. Although, the nitro-based compounds have categorized in pollutants and toxic materials which are discharge by synthetic industries after process completion, in terms of waste materials. That is why, its reduction and conversion in terms of sustainability to useful and worthy compounds are very important and the utmost needs of recent world. ${ }^{25}$

Since last few decades, metallic nanocomposites are gaining much more attention because of their efficient catalytic, opto-electronic and antibacterial properties. ${ }^{26,27}$ Although, their simple synthesis via chemical route, that is, concurrent and successive reduction of the precursor ions, gives various morphological composite nanoparticles. However, the nanoparticles have a wide surface for energy and the presence of van der Waal forces and aggregate it readily, which leads to decrease in the specific surface area that comprehensively decreases the catalytic activity. Stabilizers in the form of polymers, surfactants or any other legends are added during reduction reaction in order to protect nanosize material from aggregation..$^{28}$ Among the following types of bimetallic nanoparticles, Pd-containing bimetallic nanoparticles likePd@Ni,Pd@Au,Pd@Pt andPd@Cu are considered as promising candidates for various organic transformation reactions. ${ }^{29}$ Moreover, it has been experimentally investigated that the catalytic properties of bimetallic nanoparticles are often affected by a range of factors, like nanostructure, morphological composition of particle, size and shape. The important features that distinguish the bimetallic catalyst from monometallic ones are the tunable nanostructures and surface compositions. The bimetallic nanostructure may eventually be alloy, core-shell structure or mixed monometallic nanoparticles. These different nanostructures establish different catalytic performances. ${ }^{30}$

In the present research work, Cu, Pd and the bimetallic Pd@ $\mathrm{Cu}$ nanoparticles were synthesized through a known chemical reduction method using sodium borohydride $\left(\mathrm{NaBH}_{4}\right)$ as a reducing agent and trisodium citrate as a stabilizer. The synthesized monometallic and bimetallic nanoparticles were checked for its catalytic and antimicrobial activities. Although many researchers have reported the synthesis and characterization of $\mathrm{Cu}$ and $\mathrm{Pd}$ nanoparticles, our literature survey shows deficiencies with respect to their antimicrobial activities and catalytic properties as well as in terms of toxic environmental pollutants degradation.

\section{Experimental section Materials}

Copper nitrate trihydrates $\left(\mathrm{Cu}\left(\mathrm{NO}_{3}\right)_{2} \cdot 3 \mathrm{H}_{2} \mathrm{O}, 99 \%\right)$, palladium chloride $\left(\mathrm{PdCl}_{2}\right)$ and trisodium citrate dihydrate $\left(\mathrm{C}_{6} \mathrm{H}_{5} \mathrm{O}_{7} \mathrm{Na}_{3} \cdot 2 \mathrm{H}_{2} \mathrm{O}, 99 \%\right)$ were purchased from SigmaAldrich company and used as received without any amendment and purification. Sodium borohydride $\left(\mathrm{NaBH}_{4}, 98 \%\right)$ was used as a reducing agent for the synthesis of nanoparticles and reduction of 4-NP (99\%). The $\mathrm{NaOH}(99 \%)$, L-ascorbic acid, liquid Mueller Hinton, Luria broth (LB) and ofloxacin were purchased from Merck and Aldrich and used as received. The ultrapurified water was obtained from Milli-Q ultrapure (18.2 MN cm) system and was used in all 
the experimentation setup. The different bacterial species strains used were Proteus mirabilis, Bacillus thuringiensis, Shigella flexneri, Staphylococcus aureus, Klebsiella pneumoniae, Escherichia coli, Pseudomonas aeroginosa and Salmonella typhimurium.

\section{Synthesis of Cu, Pd and Pd@Cu bimetallic nanoparticles}

Copper nanoparticles were synthesized by the following procedure as reported by Fang et al with slight modification. ${ }^{31}$ $0.5 \mathrm{~mL}$ aqueous solution of trisodium citrate $(0.4 \mathrm{M})$ and $5.0 \mathrm{~mL}$ aqueous solution of $\mathrm{Cu}\left(\mathrm{NO}_{3}\right)_{2} \cdot 3 \mathrm{H}_{2} \mathrm{O}(0.5 \mathrm{M})$ were added in a flask containing $30 \mathrm{~mL}$ deionized (DI) water and stirred constantly. After $30 \mathrm{~min}, 0.5 \mathrm{~mL}$ freshly prepared aqueous solution of $\mathrm{NaBH}_{4}(0.1 \mathrm{M})$ was added to the mixture. The reaction was continued till their color turned deep red, indicating the synthesis of $\mathrm{Cu}$ nanoparticles. The same procedure was followed up for the synthesis of Pd nanoparticles by adding $0.5 \mathrm{~mL}$ aqueous solution of trisodium citrate $(0.4 \mathrm{M})$ and $5 \mathrm{~mL}$ aqueous solution of $\mathrm{PdCl}_{2}(0.10 \mathrm{M})$ in a flask containing $30 \mathrm{~mL}$ DI water, and stirred continuously. After $30 \mathrm{~min}, 0.5 \mathrm{~mL}$ of the already prepared aqueous solution of $\mathrm{NaBH}_{4}(0.1 \mathrm{M})$ was added into the flask. The reaction was continued under constant stirring, until the color turned to dark brown, which indicated the successful synthesis of Pd nanoparticles.

Moreover, $\mathrm{Pd}$ nanoparticles were deposited over $\mathrm{Cu}$ nanoparticles to synthesize the bimetallic Pd@Cu nanoparticles. $0.5 \mathrm{~mL} \mathrm{~L}$-ascorbic acid $(0.2 \mathrm{M})$ was added to $15 \mathrm{~mL}$ prepared Pd nanoparticles $(0.5 \mathrm{M})$ in a given flask with a constant stirring rate. After $30 \mathrm{~min}, 15 \mathrm{~mL}$ of $\mathrm{Cu}\left(\mathrm{NO}_{3}\right)_{2} \cdot 3 \mathrm{H}_{2} \mathrm{O}$ solution $(0.05 \mathrm{M})$ was added to the reaction in the presence of nitrogen gas. After $30 \mathrm{~min}, 2.5 \mathrm{~mL}$ trisodium citrate $(0.5 \%)$ was added dropwise to the reaction mixture. In the end, $2 \mathrm{~mL}$ $\mathrm{NaOH}(0.6 \mathrm{M})$ was added to the mixture dropwise to adjust the $\mathrm{pH}$ at 8.5 for $2 \mathrm{~h}$ at room temperature, to produce the bimetallic Pd@Cu nanoparticles. The resulting monometallic and bimetallic nanoparticles were centrifuged at 1,800 rpm for $20 \mathrm{~min}$. The proposed compound was gently washed and redispersed in $10 \mathrm{~mL}$ DI water.

\section{Structural characterization of $\mathrm{Cu}, \mathrm{Pd}$ and Pd@Cu bimetallic nanoparticles}

Ultraviolet-visible (UV-Vis) spectroscopy was performed using Shimadzu UV-2450 spectrometer equipped with temperature-controlled program (TCC-240A) to study the absorbance maxima and catalytic activities of synthesized monometallic and bimetallic nanoparticles. The phase purity of bimetallic Pd@Cu nanoparticles was analyzed by X-ray diffraction (XRD) using Bruker D2 PHASER $\mathrm{X}$-ray diffractometer with graphite monochromator using $\mathrm{Cu} \mathrm{K \alpha}$ radiation $(\lambda=1.54056 \AA)$, operating at $30 \mathrm{kV}$ and 15 mA. Similarly, Pd@Cu nanoparticles were characterized by energy-dispersive X-ray spectroscopy (EDS). The morphology of synthesized monometallic and bimetallic nanoparticles was studied by scanning electron microscopy (JSM 6700F). A sample was dropped on a silicon single crystal sheet, dried by infrared light and carefully placed on conducting glue. The sample was coated with gold vapor in order to make conduction for analysis by using JSM 6700F scanning electron microscope.

\section{Catalytic activities of Cu, Pd and Pd@Cu bimetallic nanoparticles}

Checking out the catalytic activity of synthesized $\mathrm{Cu}, \mathrm{Pd}$ and $\mathrm{Cu} @$ Pd bimetallic catalysts during the reduction of 4-NP to 4-aminophenol by $\mathrm{NaBH}_{4}$ was investigated as a model reaction at room temperature. During the reductive degradation of 4-NP in the presence of $\mathrm{NaBH}_{4}$, the following typical procedure was followed. Aqueous solution of each catalyst $\left(0.1 \mathrm{mg} \mathrm{mL} \mathrm{mL}^{-1}\right)$ and $\mathrm{NaBH}_{4}(0.1 \mathrm{M})$ was prepared. Forty microliters of aqueous solution of 4-NP, $150 \mu \mathrm{L}$ aqueous solution of $\mathrm{NaBH}_{4}$ and $3 \mathrm{~mL}$ DI water were added in UV quartz cell followed by adding $15 \mu \mathrm{L}$ of synthesized $\mathrm{Cu}, \mathrm{Pd}$ and $\mathrm{Pd} @ \mathrm{Cu}$ bimetallic catalysts. The progressive sequences of catalysts were investigated by changing observation in the mixture reaction at specific interval within the range of 250-500 nm under UV-Vis spectrophotometer.

During the recyclization experiment, the catalyst was isolated via centrifugation. After centrifugation, the following procedure was used to recover and reuse the catalyst. The catalyst was washed 3 times with DI water and dispersed in $10 \mu \mathrm{L}$ and reused in the subsequent reaction. The nitro compounds as 4-NP is a typical example of toxic and persistent pollutant present in industrial waste water, soil and effluents that have an adverse effect directly on the aquatic life and human health, in general. The common substance that is regulated by USA Environmental Protection Agency is 4-NP. It is considered as a model for catalytic degradation studies. The catalytic properties of citrate-stabilized $\mathrm{Cu}$ and $\mathrm{Pd}$ nanoparticles were studied for the reduction of 4-NP in the presence of excess amount of $\mathrm{NaBH}_{4}$ in a quartz cell using UV-Vis spectroscopy.

During the process, $1 \mathrm{~mL}$ aqueous solution of 4-NP $(0.1 \mathrm{mM})$ was mixed with $2 \mathrm{~mL}$ aqueous solution of $\mathrm{NaBH}_{4}(20 \mathrm{mM})$. The mixture was adjusted to the desired temperature at $30^{\circ} \mathrm{C}$ and poured into quartz cell. The catalyst temperature ( $\mathrm{Cu}$ and $\mathrm{Pd}$ nanoparticles) was adjusted to the 
same temperature. After adjusting the proposed temperature, $0.5 \mathrm{~mL}$ of $\left(0.1 \mathrm{mg} \mathrm{mL}^{-1}\right)$ each catalyst was separately added into 4-NP solution in the quartz cell to record the decrease in absorbance maxima due to reduction of 4-NP into 4-aminophenol. The reduction rate of 4-NP was determined by calculating the decrease in absorbance maxima at $400 \mathrm{~nm}$, accordingly. In case of bimetallic Pd@Cu nanoparticles, the catalytic properties were studied by using the same conditions as adjusted for monometallic $\mathrm{Pd}$ and $\mathrm{Cu}$, respectively. The temperature of mixture and bimetallic nanoparticle catalyst was separately adjusted to $30^{\circ} \mathrm{C}$ by using water bath with controlled temperature. The reduction rate of 4-NP was determined from the decrease in absorption maxima at $400 \mathrm{~nm}$, within the interval time.

\section{Antibacterial liability assessment of $\mathrm{Cu}$, Pd and Pd@Cu bimetallic nanoparticles}

The antibacterial properties of prepared $\mathrm{Cu}, \mathrm{Pd}$ and $\mathrm{Pd} @ \mathrm{Cu}$ bimetallic nanoparticles were investigated against the $\mathrm{Gram}^{+\mathrm{ve}}$ and $\mathrm{Gram}^{-\mathrm{ve}}$ bacteria using common quantitative agar disk method. ${ }^{32}$ The Gram $^{+v e}$ and Gram $^{-v e}$ bacteria culture was cultivated on LB agar media $(20 \mathrm{~mL})$ with $\mathrm{pH} 7.3$ at $25^{\circ} \mathrm{C}$. A microbial culture $(0.1 \mathrm{~mL})$ suspended in broth containing probably $10^{-6}$ colony-forming units per milliliter was spread uniformly over the surface of agar plate. The prepared $\mathrm{Cu}$, $\mathrm{Pd}$ and their bimetallic Pd@Cu nanoparticles $(15 \mu \mathrm{g}) / \mathrm{mL}$ of each catalyst were separately suspended in sterilized distilled water and a blank sterilized Whitman filter paper (No 1, diameter $4 \mathrm{~mm}$ ) was soaked in the nanoparticle suspensions.
The nanoparticle-loaded disk was put over the agar plate by using sterilized forceps.

The above experiment was repeated three times consecutively and the diameters of inhibition zones were calculated after $24 \mathrm{~h}$ at $37^{\circ} \mathrm{C}$. The antibacterial drug used as a control during the experiments was ofloxacin and the diameters of inhibition zones were measured in millimeters.

\section{Results and discussion Morphology and size of $\mathrm{Cu}, \mathrm{Pd}$ and their bimetallic Pd@Cu nanoparticles}

The morphology of citrate-stabilized monometallic $\mathrm{Cu}, \mathrm{Pd}$ and their bimetallic Pd@Cu nanoparticles was investigated using scanning electron micrographs (SEMs) technique. The SEM images of $\mathrm{Cu}$ and $\mathrm{Pd}$ nanoparticles showed monodisparity and spherical shape as shown in Figure 1A and B corresponding to their size distribution plots. The average size of $\mathrm{Cu}$ and $\mathrm{Pd}$ nanoparticles determined by nanomeasure software were adjusted as 40 and $50 \mathrm{~nm}$, respectively. The particle sizes were determined by nanomeasure software. ${ }^{33}$

Similarly, the morphology and size distribution of bimetallic Pd@Cu nanoparticles were studied using SEM as shown in Figure $1 \mathrm{C}$ with the corresponding size distribution plots. It was observed that the average size of bimetallic $\mathrm{Pd} @ \mathrm{Cu}$ nanoparticles measured by nanomeasure software was $380 \mathrm{~nm}(0.38 \mu \mathrm{m})$. Meanwhile, XRD analysis of the bimetallic Pd@Cu nanoparticles was carried out as shown in Figure 2. The composition and structural verification of the prepared Pd@Cu bimetallic nanoparticles by using the XRD

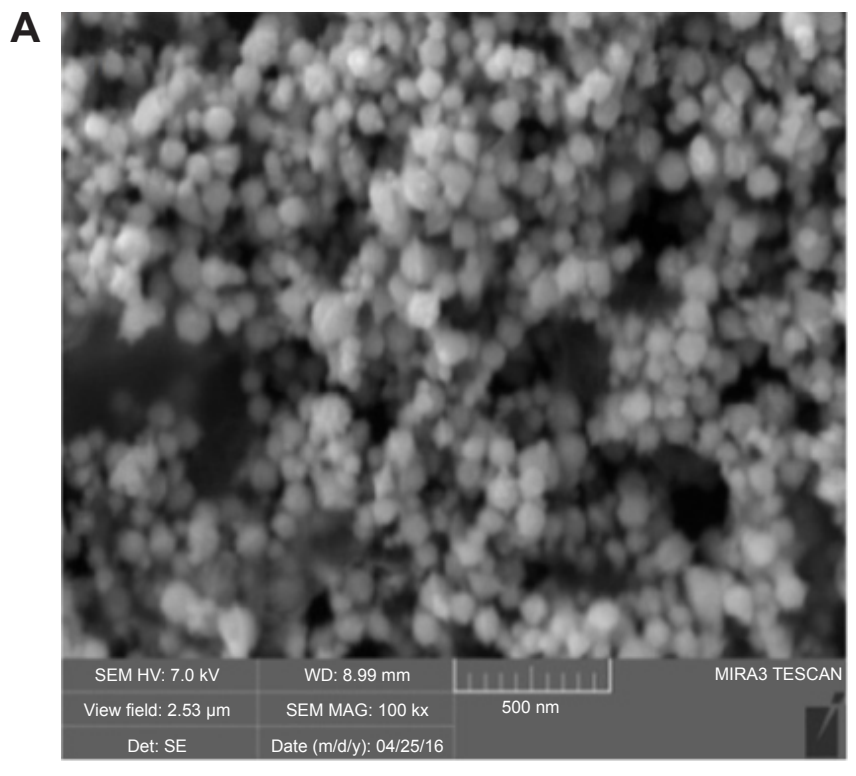

A

Figure I (Continued)

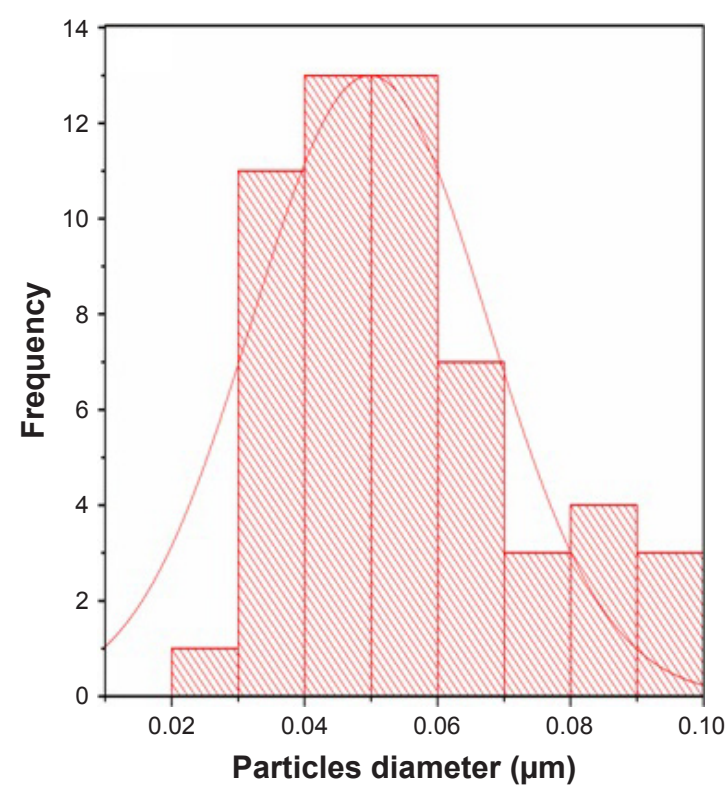



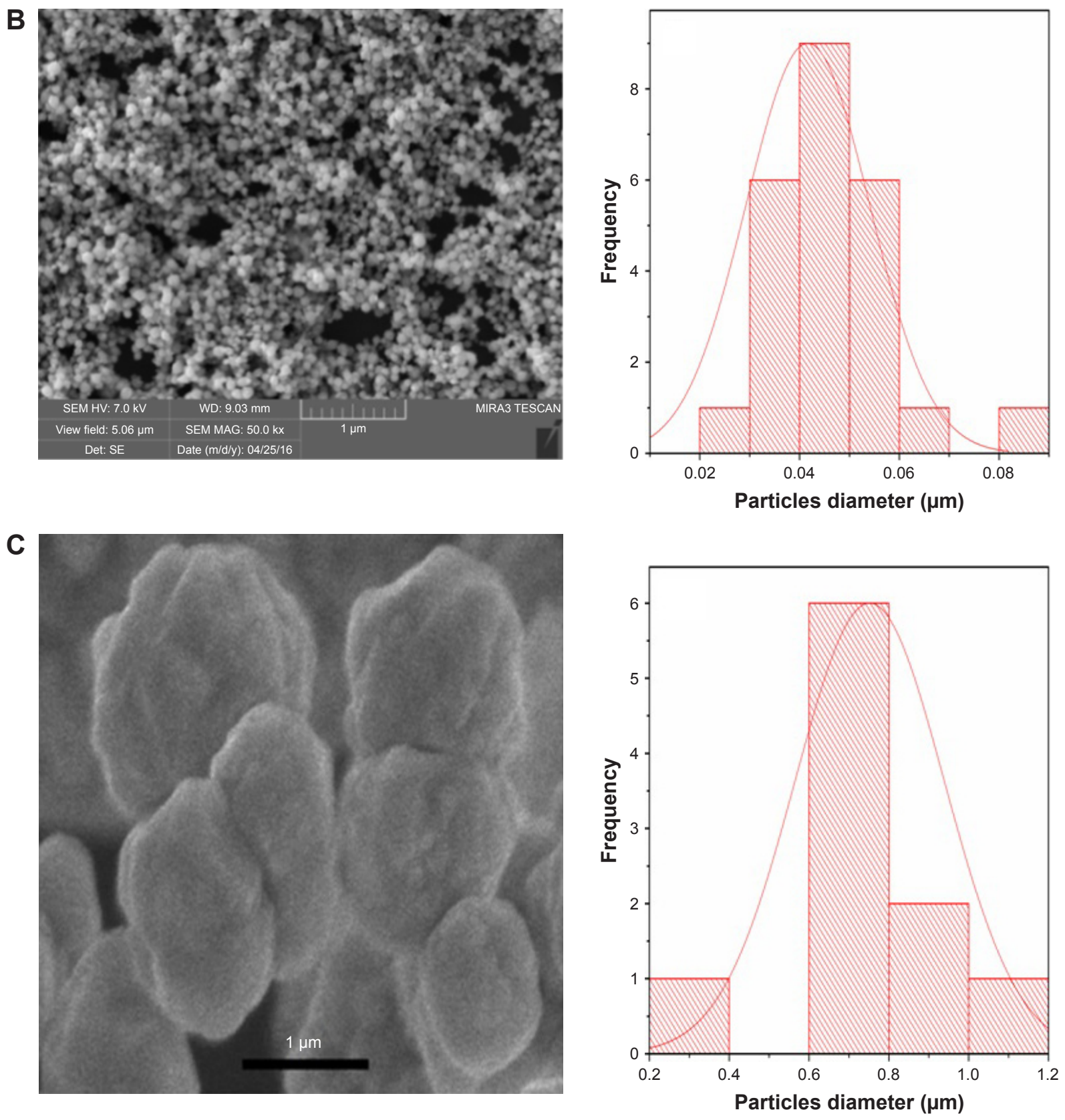

Figure I Scanning electron micrographs and size distribution plots of (A) copper, (B) palladium and (C) palladium@copper bimetallic nanoparticles.

and energy-dispersive X-ray are shown in Figure 2A and B, respectively. The XRD peaks caused by $\mathrm{Cu}-\mathrm{Pd}$ bimetallic nanoparticles indexed as a face-centered cubic structure among $2 / 3$ lie on the pure face-centered cubic Pd (JCPDS no 46-1043).

Meanwhile, lattice parameters of $\mathrm{Cu} @ \mathrm{Pd}$ bimetallic nanoparticle constituents suggest the possibility of alloy structure. A thin film of bimetallic Pd@Cu nanoparticle sample exhibited diffraction peaks at $41,48,70,85$ and $90^{\circ}$ corresponding to the crystal surfaces $111,200,220,311$ and 222, respectively, compared to the standard diffraction pattern. ${ }^{34}$ The confirmation of each nanoparticle, that is, $\mathrm{Pd}$, $\mathrm{Cu}$ and alloy, formation was proved by energy-dispersive $\mathrm{X}$-ray elemental mapping analysis as shown in Figure 2 (B1-3). The Pd@Cu bimetallic nanoparticle composition was proved by using the EDS and the Pd and $\mathrm{Cu}$ detected the peaks of Mo- and carbon-coated SEM grid as shown in Figure S1.

The three types of metal nanoparticles, that is, $\mathrm{Cu}, \mathrm{Pd}$ and their bimetallic nanoparticles, were prepared by using different volumes $(0.2-0.6 \mathrm{~mL})$ of trisodium citrate. The effect of change in amount of trisodium citrate was studied by using 

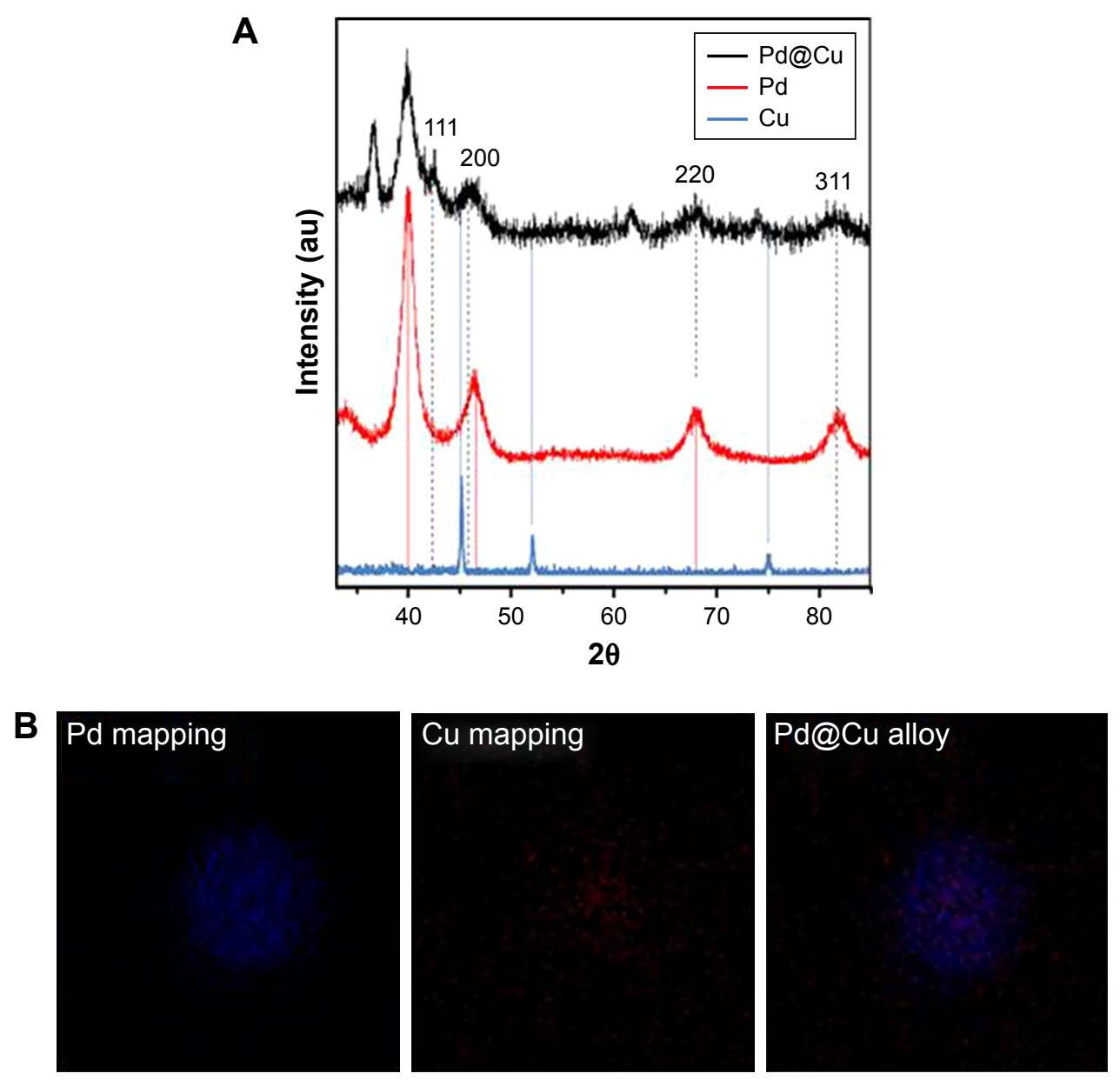

Figure 2 (A) X-ray diffraction pattern of palladium@copper bimetallic nanoparticles. (B) Energy-dispersive X-ray elemental mapping images of Pd, Cu, and Pd@Cu bimetallic nanoparticles, respectively.

UV-Vis spectroscopy and the relative change in absorbance maxima for $\mathrm{Cu}, \mathrm{Pd}$ and $\mathrm{Pd} @ \mathrm{Cu}$ bimetallic nanoparticles as shown in Figure 3A-C. The absorbance maxima appeared at 600 and $400 \mathrm{~nm}$ for $\mathrm{Cu}$ and $\mathrm{Pd}$ nanoparticles for the different volumes of trisodium citrate. Similar results were obtained for bimetallic Pd@Cu nanoparticles and their absorbance maxima appeared at $415 \mathrm{~nm}$ for different volumes of trisodium citrate. The appearance of absorbance maxima for $\mathrm{Pd} @ \mathrm{Cu}$ nanoparticles at $415 \mathrm{~nm}$ showed good deposition of $\mathrm{Pd}$ nanoparticles over $\mathrm{Cu}$ nanoparticles, and the absorbance maxima of bimetallic nanoparticles were very close to the absorbance maxima of Pd nanoparticles. Moreover, the stability of absorbance maxima for the volume of trisodium citrate indicated the synthesis of same-size $\mathrm{Cu}, \mathrm{Pd}$ and bimetallic Pd@Cu nanoparticles, ${ }^{7}$ whereas the increase in absorption peak intensity showed increase in the synthesis of nanoparticles per unit area in medium with increase in volume of trisodium citrate.

\section{Catalytic activities of $\mathrm{Cu}, \mathrm{Pd}$ and their bimetallic Pd@Cu nanoparticles}

The catalytic properties of prepared monometallic $\mathrm{Cu}, \mathrm{Pd}$ and their bimetallic Pd@Cu nanoparticles were investigated by reducing 4-NP to 4-aminophenol in the presence of excess amount of $\mathrm{NaBH}_{4}$ as a reducing agent. The reduction process was monitored by UV-Vis spectroscopy at regular intervals. After the addition of $\mathrm{NaBH}_{4}$ to aqueous solution of 4-NP, the color of the solution changed from light yellow to deep yellow because of conversion of 4-NP to 4-nitropheolate ion as shown in Figure 4A. Similarly, the absorption maxima of 4-NP changed from 318 to $400 \mathrm{~nm}$ because of conversion of 4-NP into 4-nitropheolate ion in the presence of $\mathrm{NaBH}_{4}$, and is presented in Figure 4B. ${ }^{35}$ It was also investigated that neither metal nanoparticles nor $\mathrm{NaBH}_{4}$ alone can degrade the 4-NP ${ }^{5}$. However, by the addition of metal nanoparticles, that is, $\mathrm{Cu}, \mathrm{Pd}$ and $\mathrm{Pd} @ \mathrm{Cu}$ bimetallic nanoparticles, into an aqueous solution of 4-NP in the presence of $\mathrm{NaBH}_{4}$, 

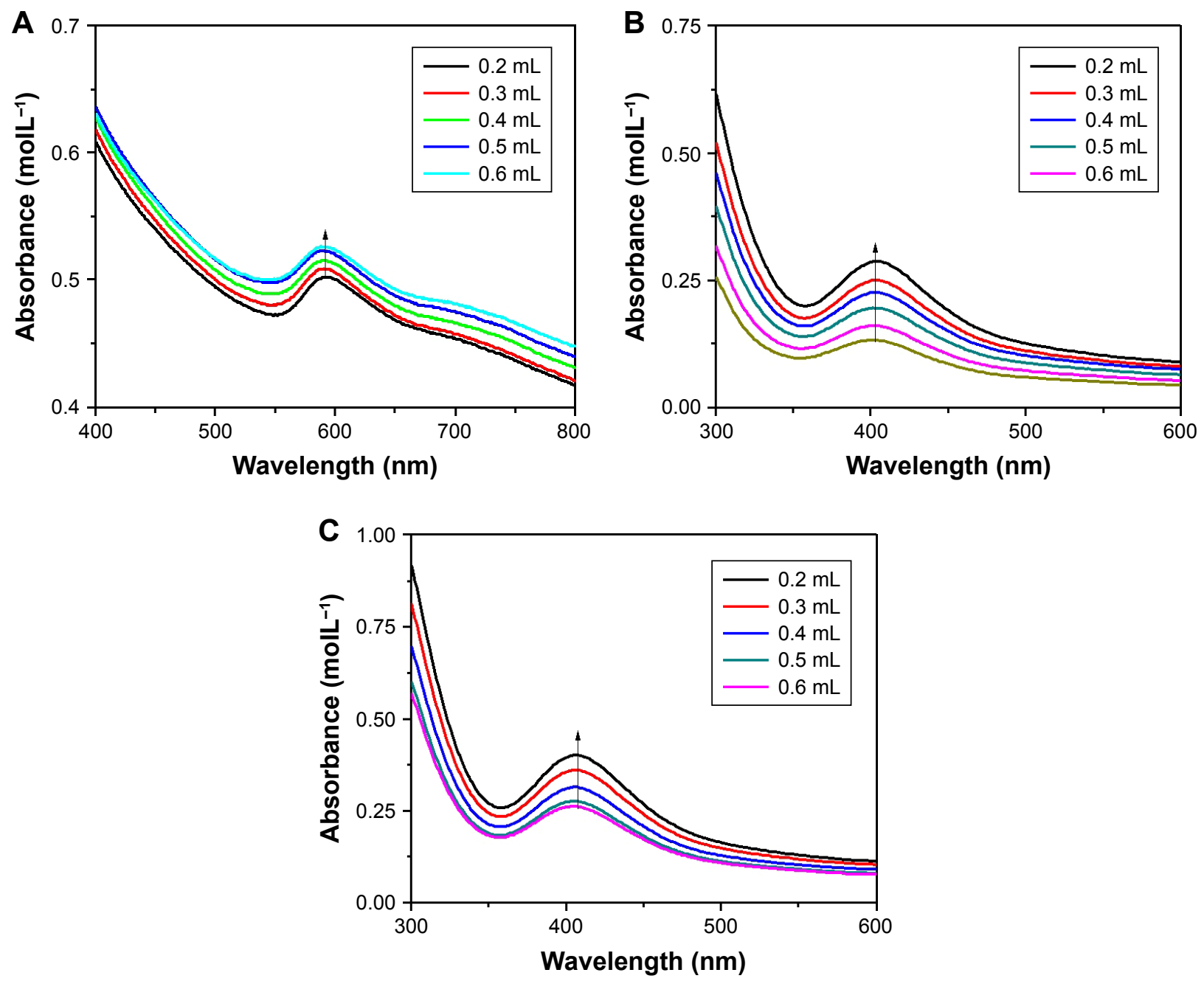

Figure 3 Absorbance spectra of (A) copper, (B) palladium and (C) palladium@copper bimetallic nanoparticles using different volumes of trisodium citrate (5 mM). The arrows show the maximum absorbance.

a sharp decrease in absorption maxima was observed for 4-nitrophenolate ions as shown in Figure 5A-C. The peak that appeared at $300 \mathrm{~nm}$ is assigned to the formation of 4-aminophenols. ${ }^{36}$ The apparent rate $\left(k_{\text {aap }}\right)$ constant and correlation constants $\left(R^{2}\right)$ for $\mathrm{Cu}, \mathrm{Pd}$ and $\mathrm{Pd} @ \mathrm{Cu}$ nanoparticles were calculated by plotting $\ln \left(\mathrm{C}_{\mathrm{t}} / \mathrm{C}_{\mathrm{o}}\right)$ versus reaction time for the reduction of 4-NP (Figure 6). The slopes of graph indicate pseudo first-order kinetics. ${ }^{5}$ The apparent rate constants for $\mathrm{Cu}, \mathrm{Pd}$ and $\mathrm{Pd} @ \mathrm{Cu}$ bimetallic nanoparticles were determined from the slopes of linear curve, which were $0.3322 \mathrm{~min}^{-1}$, $0.2689 \mathrm{~min}^{-1}$ and $1.812 \mathrm{~min}^{-1}$, respectively. It was observed that the correlation coefficients $\left(R^{2}\right)$ were above 0.99 for all the three types of synthesized nanoparticles. The reduction rate was found to increase 6 times with doping Pd nanoparticles over $\mathrm{Cu}$ nanoparticles $(\mathrm{Pd} @ \mathrm{Cu})$ as compared to monometallic $\mathrm{Cu}$ and $\mathrm{Pd}$ nanoparticles. The catalyst was recycled 7 times consecutively by centrifugation at $14,000 \mathrm{rpm}$ and used reduction of 4-NP, with the observation of $1 \%$ deficiencies in reuse activity.

\section{Comparative antibacterial properties of $\mathrm{Cu}, \mathrm{Pd}$ and their bimetallic Pd@Cu nanoparticles}

The researchers have been forced to discover some new antibacterial agents to eliminate the risk of multidrug-resistant bacterial strains. For this purpose, we have compared the antibacterial activates of citrate-stabilized Cu, Pd and Pd@ $\mathrm{Cu}$ bimetallic nanoparticles. In the reported study, different nanoparticles against the eight different strains of bacteria were tested. Among these series of setup, B. thuringiensis and $S$. aureus were found to be the positive strains and the rest, Proteus mirabilis, Shigella flexneri, Klebsiella pneumonia, Pseudomonas aeruginosa, S. typhimurium and Escherichia coli, were recorded as the negative strains. With reference to 
A

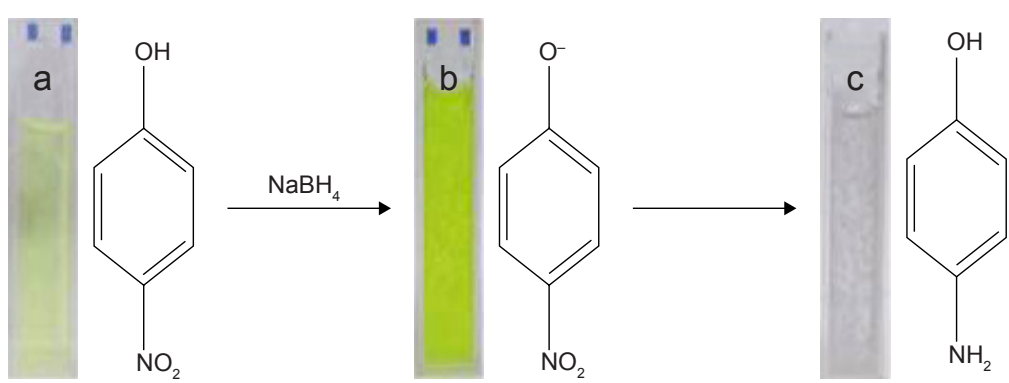

4-nitrophenol

4-nitrophenolate ion

4-aminophenol

B

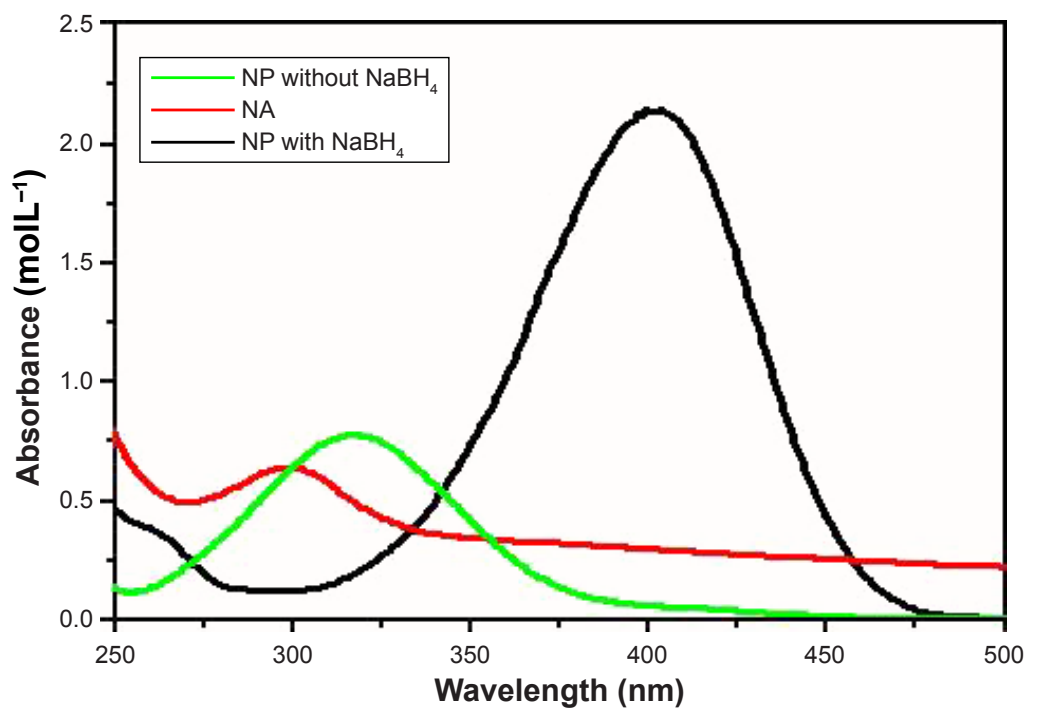

Figure 4 (A) Color change during catalytic reduction of 4-nitrophenol to 4-aminophenol and (B) ultraviolet-visible spectra of p-nitrophenol, p-nitrophenolate ion and 4-aminophenol. Reaction conditions: $\mathrm{H}_{2} \mathrm{O}(3 \mathrm{~mL})$, Cu@Pd (I5 $\mu \mathrm{L}, 0.1$ mg mL $\mathrm{mL}^{-1}$, 4-nitrophenol $(55 \mu \mathrm{L}, 0.1 \mathrm{M})$ and NaBH $(\mathrm{I} 50 \mu \mathrm{L}, 0.1 \mathrm{M})$. (a) 4-nitrophenol, (b) 4-nitrophenolate ion, (c) 4-aminophenol.

Abbreviations: NA, nitroaminophenol; NP, nitrophenol.

our literature survey, it was found that $\mathrm{Cu}$ and $\mathrm{Cu}$-containing nanocomposites had a better antibacterial activity. Therefore, in this work, we have checked out in detail the antibacterial activates of $\mathrm{Cu}, \mathrm{Pd}$ and their composites through disk diffusion method against the various bacterial strains, that is, $\mathrm{Gram}^{+\mathrm{ve}}$ and $\mathrm{Gram}^{-\mathrm{ve}}$.

According to the diffusion method, the antimicrobial properties of $\mathrm{Cu}, \mathrm{Pd}$ and $\mathrm{Pd} @ \mathrm{Cu}$ bimetallic nanoparticles were checked against the $\mathrm{Gram}^{+\mathrm{ve}}$ bacteria $B$. thuringiensis and $S$. aureus. At $37^{\circ} \mathrm{C}$ after 24 h of incubation, the diameters of inhibitions zones were calculated and found that both the $\mathrm{Cu}$ and $\mathrm{Cu} @ \mathrm{Pd}$ bimetallic nanoparticles had a better sensitivity over both strains of bacteria except $\mathrm{Pd}$, which has no zone of inhibition in the presence of positive control ofloxacin. Kora and Rastogi have investigated that Pd nanoparticles have no antibacterial activities. ${ }^{37}$ The zones of inhibition of Cu nanoparticles against $B$. thuringiensis and $S$. aureus were found to be at $14 \pm 0$ and $16 \pm 0 \mathrm{~nm}$, respectively, as shown in Figure S2A and B. The positive control plate loaded with ofloxacin has a zone of inhibition at $16 \mathrm{~mm}$. The zone of inhibition of Pd@Cu bimetallic nanoparticles was observed at $17 \pm 0$ and $20 \pm 0 \mathrm{~mm}$. The positive control ofloxacin had presented the zone of inhibitions at about $19 \pm 0 \mathrm{~mm}$.

Similarly, the same nanoparticles were used against $\mathrm{Gram}^{-\mathrm{ve}}$ bacterial strains Proteus mirabilis, Shigella flexneri, Klebsiella pneumonia, Pseudomonas aeruginosa, S. typhimurium and E. coli to check out in detail the antibacterial properties. The inhibition zones of $\mathrm{Cu}$ nanoparticles against the above-mentioned negative bacterial species strains were recorded as $17 \pm 0,12 \pm 0,12 \pm 0,15 \pm 0,12 \pm 0$ and $19 \pm 0 \mathrm{~mm}$, respectively. The positive control sides of ofloxacin inhibition zone against the proposed negative bacterial strains were found as $18 \pm 0,16 \pm 0,14 \pm 0,17 \pm 0,15 \pm 0$ and $20 \pm 0 \mathrm{~mm}$, respectively, as shown in Figure $\mathrm{S} 2 \mathrm{C}-\mathrm{H}$.

The inhibition zones of $\mathrm{Pd} @ \mathrm{Cu}$ bimetallic nanoparticles against the six negative bacterial species strains presented above are at $19 \pm 0,18 \pm 0,17 \pm 0,18 \pm 0$ and $16 \pm 0,25 \mathrm{~mm}$, respectively, as shown in Figure S2A-H. The diameter of inhibition zones was different for different bacterial strains for $\mathrm{Cu}, \mathrm{Pd}$ and $\mathrm{Cu} @ \mathrm{Pd}$ bimetallic nanoparticles. This difference in the diameter of inhibition zone was due to the composition of bacterial cell wall. The zone of inhibition of 

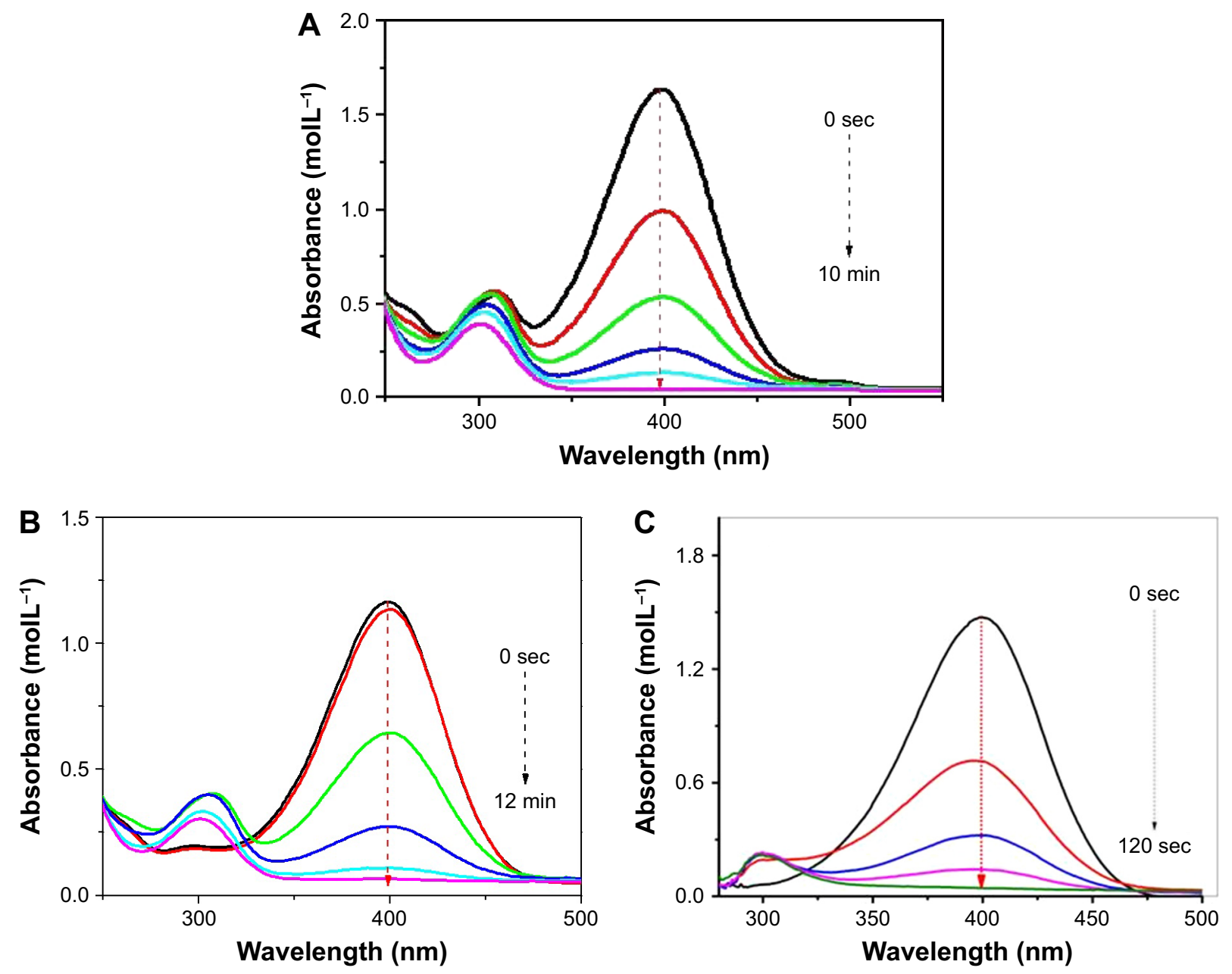

Figure 5 Ultraviolet-visible spectra for the reduction of 4-nitrophenol catalyzed by $(\mathbf{A})$ copper, $(\mathbf{B})$ palladium and $(\mathbf{C})$ palladium@copper bimetallic nanoparticles. Notes: Reaction conditions: $\mathrm{H}_{2} \mathrm{O}(3 \mathrm{~mL}), \mathrm{Cu}(15 \mu \mathrm{L}, 0.1 \mathrm{mg} \mathrm{mL}-1)$, 4-nitrophenol $(40 \mu \mathrm{L}, 0.1 \mathrm{M})$ and $\mathrm{NaBH}_{4}(\mathrm{I} 50 \mu \mathrm{L}, 0.1 \mathrm{M})$. (B) Conditions: $\mathrm{H}_{2} \mathrm{O}(3 \mathrm{~mL}), \mathrm{Pd}\left(\mathrm{I} 5 \mu \mathrm{L}, 0.1 \mathrm{mg} \mathrm{mL}^{-1}\right)$, 4-nitrophenol $(40 \mu \mathrm{L}, 0.1 \mathrm{M})$ and $\mathrm{NaBH}_{4}(150 \mu \mathrm{L}, 0.1 \mathrm{M})$. (C) Conditions: $\mathrm{H}_{2} \mathrm{O}(3 \mathrm{~mL}), \mathrm{Pd} @ \mathrm{Cu}\left(\mathrm{I} 5 \mu \mathrm{L}, 0.1 \mathrm{mg} \mathrm{mL}^{-1}\right)$, 4-nitrophenol (40 $\left.\mu \mathrm{L}, 0.1 \mathrm{M}\right)$ and NaBH (I50 $\left.\mu \mathrm{L}, 0.1 \mathrm{M}\right)$.

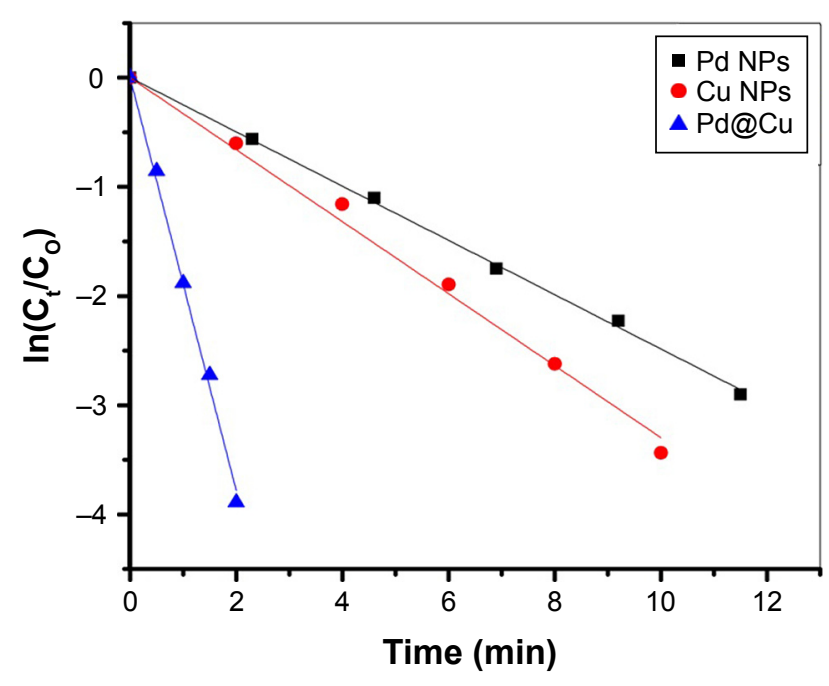

Figure 6 Determination of the reduction rates of 4-nitrophenol as a function of reaction time by using copper, palladium and palladium@copper bimetallic nanoparticles as a catalyst.

Notes: Reaction conditions: $\mathrm{H}_{2} \mathrm{O}(3 \mathrm{~mL}), \mathrm{Cu}(15 \mu \mathrm{L}, 0.1 \mathrm{mg} \mathrm{mL}-1)$, 4-nitrophenol $(40 \mu \mathrm{L}, 0.1 \mathrm{M})$ and $\mathrm{NaBH}_{4}(\mathrm{I} 50 \mu \mathrm{L}, 0.1 \mathrm{M})$. (b) Reaction conditions: $\mathrm{H}_{2} \mathrm{O}(3 \mathrm{~mL})$, Pd (I5 $\left.\mu \mathrm{L}, 0.1 \mathrm{mg} \mathrm{mL} \mathrm{L}^{-1}\right)$, 4-nitrophenol (40 $\left.\mu \mathrm{L}, 0 . \mathrm{I} \mathrm{M}\right)$ and $\mathrm{NaBH}_{4}(\mathrm{I} 50 \mu \mathrm{L}, 0 . \mathrm{I} \mathrm{M})$. (c) Reaction conditions: $\mathrm{H}_{2} \mathrm{O}(3 \mathrm{~mL})$, Pd@Cu (I5 $\left.\mu \mathrm{L}, 0.1 \mathrm{mg} \mathrm{mL} \mathrm{m}^{-1}\right)$, 4-nitrophenol $(40 \mu \mathrm{L}, 0.1 \mathrm{M})$ and $\mathrm{NaBH}_{4}(150 \mu \mathrm{L}, 0 . \mathrm{I} \mathrm{M})$.
The bimetallic $\mathrm{Cu} @$ Pd nanoparticles zone of inhibition was reported with maximum range rather than the standard ofloxacin, which shows that these bimetallic nanoparticles are more effective against all the bacterial strains. The citrate-stabilized $\mathrm{Pd} @ \mathrm{Cu}$ nanoparticles have shown maximum antibacterial activities than the reported work in our existing literature. ${ }^{38,39}$

\section{Conclusion}

The present research work focuses its efforts to synthesize the monodispersed $\mathrm{Cu}, \mathrm{Pd}$ and their bimetallic Pd@Cu nanoparticles via known chemical reduction process in the presence of trisodium citrate as stabilizer. The synthesized monometallic and bimetallic nanoparticles had a remarkable stability and increase in amount with increase in volume of trisodium citrate. The highly catalytic and antibacterial activities were observed with bimetallic Pd@Cu nanoparticles. The catalytic activities of monometallic and bimetallic nanoparticles were gaged on 4-NP and an increase up to 6 times on doping Pd nanoparticles over $\mathrm{Cu}$ nanoparticles $(\mathrm{Pd} @ \mathrm{Cu})$ as 
compared to their monometallic nanoparticles was observed. Meanwhile, the antibacterial activities were carried out on two $\mathrm{Gram}^{+\mathrm{ve}}$ and six $\mathrm{Gram}^{-\mathrm{ve}}$ bacterial strains. The bimetallic nanoparticles had shown the maximum antibacterial activities as compared to monometallic $\mathrm{Cu}$ and $\mathrm{Pd}$ nanoparticles. Moreover, the antibacterial activities of bimetallic $\mathrm{Pd} @ \mathrm{Cu}$ nanoparticles were found at a maximum level than the used standard antibacterial drug ofloxacin. It is recommended that the developed findings in terms of catalytic property and antibacterial activities of the proposed compounds will enable the use of bimetallic nanoparticles in the field of catalysis and nanomedicine.

\section{Acknowledgments}

All the authors extend their gratitude to the Higher Education Commission of Pakistan (HEC) and the technical facilities provided by the Department of Biosciences, COMSATS Institute of Information Technology, Islamabad-Pakistan.

\section{Disclosure}

The authors report no conflicts of interest in this work.

\section{References}

1. Becker S. Nanotechnology in the marketplace: how the nanotechnology industry views risk. J Nanoparticle Res. 2013;15(5):1-13.

2. Rai M, Yadav A, Gade A. Silver nanoparticles as a new generation of antimicrobials. Biotechnol Adv. 2009;27(1):76-83.

3. Sanvicens N, Marco MP. Multifunctional nano-particles properties and prospects for their use in human medicine. Trends Biotechnol. 2008; 26(8):425-433.

4. Guo S, Li D, Zhang L, Li J, Wang E. Monodisperse mesoporous superparamagnetic single-crystal magnetite nanoparticles for drug delivery. Biomaterials. 2009;30(10):1881-1889.

5. Rehman S, Siddiq M, Al-Lohedan H, Sahiner N. Cationic microgels embedding metal nanoparticles in the reduction of dyes and nitrophenols. Chemical Engineering Journal. 2015;265:201-209.

6. Qi W, Wang M. Size and shape dependent melting temperature of metallic nanoparticles. Materials chemistry and physics. 2004;88(2): 280-284.

7. Rehman SU, Shah SM, Siddiq M. Synthesis and Optical Studies of Silver Nanoparticles (Ag NPs) and their Hybrids of Smart Polymer Microgel. J Chem Soc Pak. 2013;35(3):718-726.

8. Tien HW, Huang YL, Yang SY, Wang JY, Ma CCM. The production of graphene nanosheets decorated with silver nanoparticles for use in transparent, conductive films. Carbon. 2011;49(5):1550-1560.

9. Gojny FH, Wichmann MH, Fiedler B, Schulte K. Influence of different carbon nanotubes on the mechanical properties of epoxy matrix composites-a comparative study. Composites Sci Technol. 2005;65(15): 2300-2313.

10. Jain KK. The role of nanobiotechnology in drug discovery. Drug Discovery Today. 2005;10(21):1435-1442.

11. Xu P, Zeng GM, Huang DL, et al. Use of iron oxide nanomaterials in wastewater treatment: a review. Sci Total Environ. 2012;424:1-10.

12. Kumar P, Robins A, Vardoulakis S, Britter R. A review of the characteristics of nanoparticles in the urban atmosphere and the prospects for developing regulatory controls. Atmospheric Environ. 2010;44(39): 5035-5052.
13. Nair MG, Nirmala M, Rekha K, Anukaliani A. Structural, optical, photo catalytic and antibacterial activity of $\mathrm{ZnO}$ and Co doped $\mathrm{ZnO}$ nanoparticles. Materials Letters. 2011;65(12):1797-1800.

14. Tolaymat TM, El Badawy AM, Genaidy A, Scheckel KG, Luxton TP, Suidan M. An evidence-based environmental perspective of manufactured silver nanoparticle in syntheses and applications: a systematic review and critical appraisal of peer-reviewed scientific papers. Sci Total Environ. 2010;408(5):999-1006.

15. Rehman S, Siddiq M, Al-Lohedan H, et al. Fast removal of high quantities of toxic arsenate via cationic p (APTMACl) microgels. J Environ Management. 2016;166:217-226.

16. Wang $\mathrm{H}$, Ren ZJ. Bioelectrochemical metal recovery from wastewater: a review. Water Res. 2014;66:219-232.

17. Brayner R, Vaulay M-J, Fiévet F, Coradin T. Alginate-mediated growth of $\mathrm{Co}, \mathrm{Ni}$, and CoNi nanoparticles: influence of the biopolymer structure. Chem Mater. 2007;19(5):1190-1198.

18. Liz-Marzán LM. Nanometals: formation and color. Materials Today. 2004;7(2):26-31.

19. Park BK, Jeong S, Kim D, Moon J, Lim S, Kim JS. Synthesis and size control of monodisperse copper nanoparticles by polyol method. J Colloid Interface Sci. 2007;311(2):417-424.

20. Ruparelia JP, Chatterjee AK, Duttagupta SP, Mukherji S. Strain specificity in antimicrobial activity of silver and copper nanoparticles. Actabiomaterialia. 2008;4(3):707-716.

21. Perreault F, Popovic R, Dewez D. Different toxicity mechanisms between bare and polymer-coated copper oxide nanoparticles in Lemnagibba. Environ Pollut. 2014;185:219-227.

22. Adlim M, Bakar MA, Liew KY, Ismail J. Synthesis of chitosanstabilized platinum and palladium nanoparticles and their hydrogenation activity. J Mol Catalysis A Chem. 2004;212(1):141-149.

23. Liu Z, Hong L, Tham MP, Lim TH, Jiang H. Nanostructured Pt/C and $\mathrm{Pd} / \mathrm{C}$ catalysts for direct formic acid fuel cells. J Power Sources. 2006; 161(2):831-835.

24. Chen Xm, Cai Zx, Huang Zy, Oyama M, Jiang Yq, Chen X. Ultrafine palladium nanoparticles grown on graphene nanosheets for enhanced electrochemical sensing of hydrogen peroxide. Electrochimica Acta. 2013;97:398-403.

25. Ajmal M, Siddiq M, Al-Lohedan H, Sahiner N. Highly versatile $p$ (MAc)-M (M: $\mathrm{Cu}, \mathrm{Co}, \mathrm{Ni})$ microgel composite catalyst for individual and simultaneous catalytic reduction of nitro compounds and dyes. RSC Adv. 2014;4(103):59562-59570.

26. Sheny D, Mathew J, Philip D. Phytosynthesis of $\mathrm{Au}, \mathrm{Ag}$ and $\mathrm{Au}-\mathrm{Ag}$ bimetallic nanoparticles using aqueous extract and dried leaf of Anacardiumoccidentale. Spectrochim Acta Part A Mol Biomol Spectrosc. 2011;79(1):254-262.

27. Prieto P, Nistor V, Nouneh K, Oyama M, Abd-Lefdil M, Díaz R. XPS study of silver, nickel and bimetallic silver-nickel nanoparticles prepared by seed-mediated growth. Appl Surf Sci. 2012;258(22):8807-8813.

28. Sahiner M, Sel K, Siddiq M, Sahiner N. Synthesis and characterization of new microgel from tris (2-aminoethyl) amine and glycerol diglycidyl ether as poly (TAEA-co-GDE). Colloids Surf B Biointerfaces. 2015;136:1156-1165.

29. Chen A, Ostrom C. Palladium-based nanomaterials: synthesis and electrochemical applications. Chemical Rev. 2015;115(21):11999-12044.

30. Liu X, Wang A, Li L, Zhang T, Mou CY, Lee JF. Structural changes of $\mathrm{Au}-\mathrm{Cu}$ bimetallic catalysts in CO oxidation: in situ XRD, EPR, XANES, and FT-IR characterizations. J Catalysis. 2011;278(2):288-296.

31. Fang J, Zhong C, Mu R. The study of deposited silver particulate films by simple method for efficient SERS. Chem Phys Lett. 2005; 401(1):271-275.

32. Andrews JM. The development of the BSAC standardized method of disc diffusion testing. J Antimicrob Chemother. 2001;48(Suppl 1): 29-42.

33. Sohail M, Xue H, Jiao Q, et al. Synthesis of well-dispersed TiO 2@ reduced graphene oxide (rGO) nanocomposites and their photocatalytic properties. Mater Res Bull. 2017;90:125-130. 
34. Heshmatpour F, Abazari R, Balalaie S. Preparation of monometallic $(\mathrm{Pd}, \mathrm{Ag})$ and bimetallic $(\mathrm{Pd} / \mathrm{Ag}, \mathrm{Pd} / \mathrm{Ni}, \mathrm{Pd} / \mathrm{Cu})$ nanoparticles via reversed micelles and their use in the Heck reaction. Tetrahedron. 2012; 68(14):3001-3011.

35. Sahiner N, Ozay H, Ozay O, Aktas N. New catalytic route: hydrogels as templates and reactors for in situ Ni nanoparticle synthesis and usage in the reduction of 2- and 4-nitrophenols. Appl Catalysis A General. 2010; 385(1):201-207.

36. Mogudi BM, Ncube P, Meijboom R. Catalytic activity of mesoporous cobalt oxides with controlled porosity and crystallite sizes: Evaluation using the reduction of 4-nitrophenol. Appl Catalysis B Environ. 2016; 198:74-82.
37. Kora AJ, Rastogi L. Green synthesis of palladium nanoparticles using gum ghatti (Anogeissus latifolia) and its application as an antioxidant and catalyst. Arabian J Chem. 2015;2:450-457.

38. Paladini F, Pollini M, Sannino A, Ambrosio L. Metal-based antibacterial substrates for biomedical applications. Biomacromolecules. 2015;16(7): 1873-1885.

39. Díaz-Visurraga J, Daza C, Pozo C, Becerra A, von Plessing C, García A. Study on antibacterial alginate-stabilized copper nanoparticles by FT-IR and 2D-IR correlation spectroscopy. Int J Nanomedicine. 2012 ; $7: 3597-3612$ 


\section{Supplementary materials}

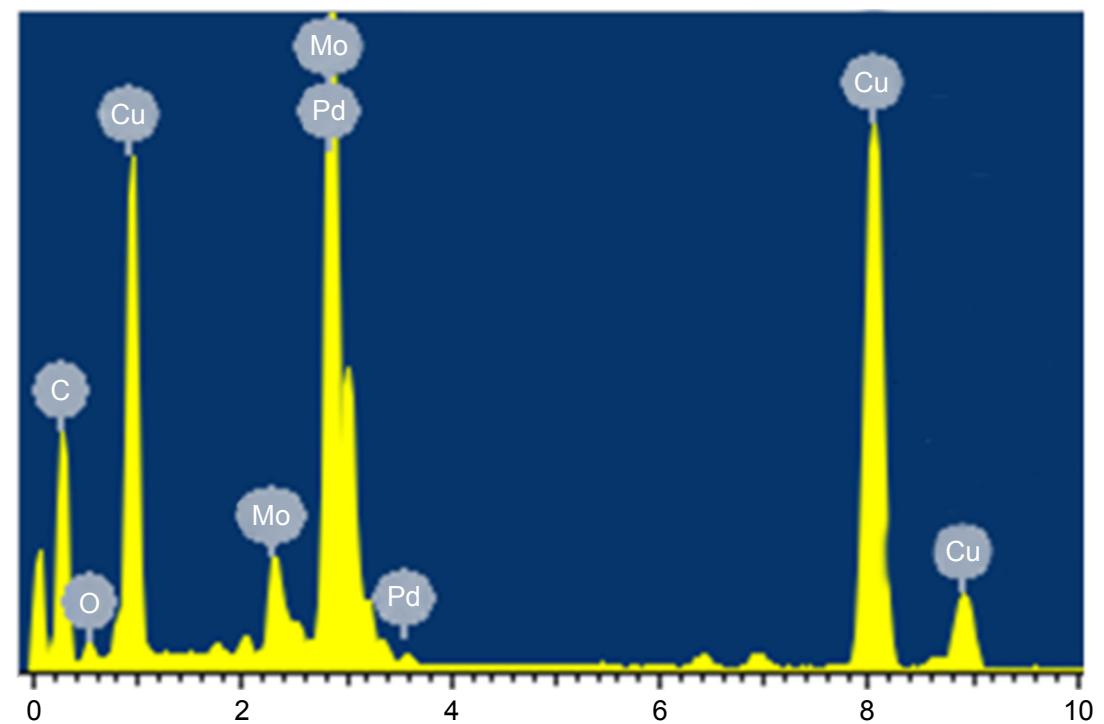

Figure SI Energy-dispersive X-ray spectrum of Pd@Cu nanoparticles.
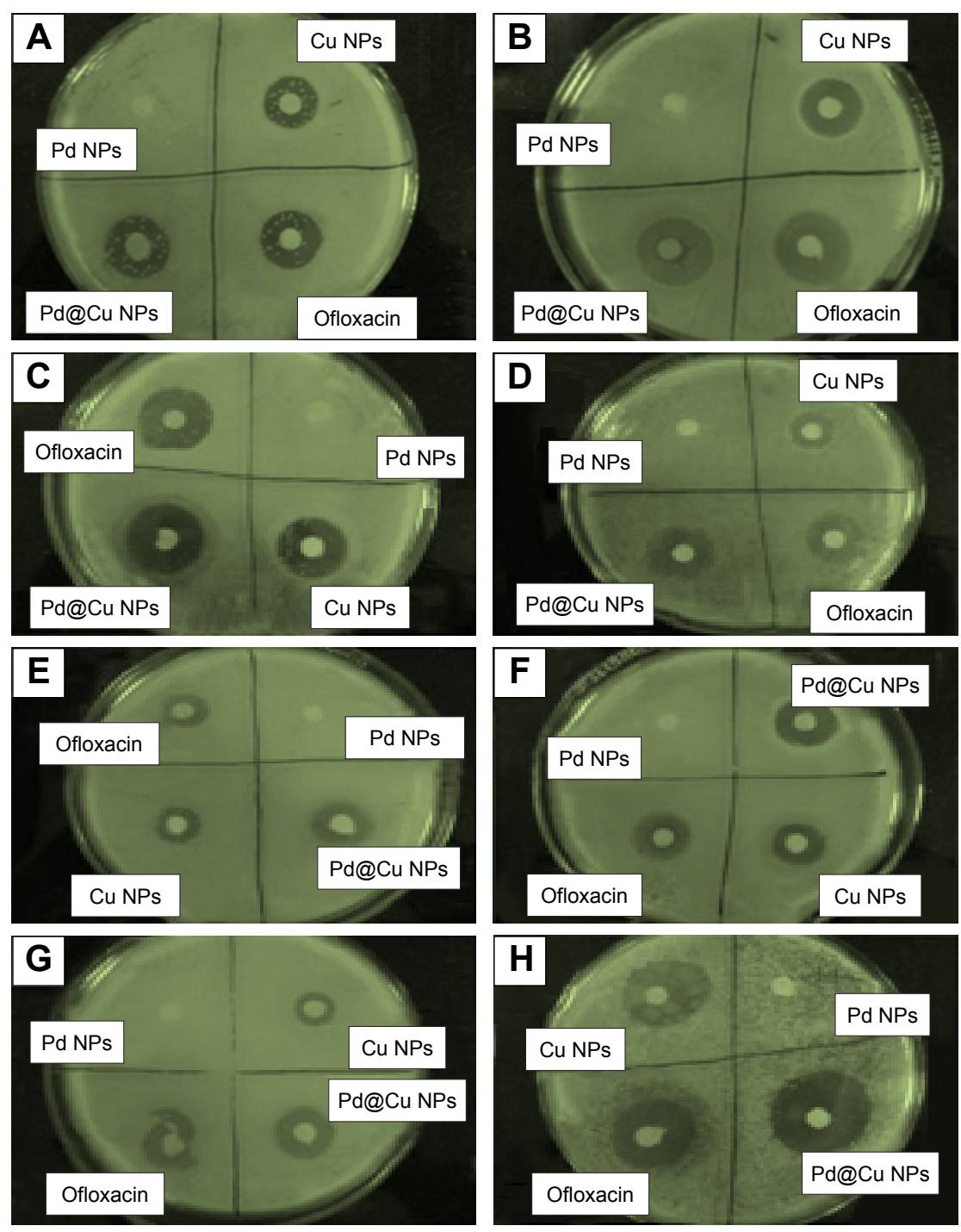

Figure S2 Comparative antibacterial properties of copper, palladium and their bimetallic palladium@copper nanoparticles: (A, B) Grame; $(\mathbf{C}-\mathbf{H})$ Gram ${ }^{\text {-ve }}$ bacteria. 
International Journal of Nanomedicine

Dovepress

\section{Publish your work in this journal}

The International Journal of Nanomedicine is an international, peerreviewed journal focusing on the application of nanotechnology in diagnostics, therapeutics, and drug delivery systems throughou the biomedical field. This journal is indexed on PubMed Central, MedLine, CAS, SciSearch ${ }^{\circledR}$, Current Contents ${ }^{\circledR} /$ Clinical Medicine,
Journal Citation Reports/Science Edition, EMBase, Scopus and the Elsevier Bibliographic databases. The manuscript management system is completely online and includes a very quick and fair peer-review system, which is all easy to use. Visit http://www.dovepress.com/ testimonials.php to read real quotes from published authors.

Submit your manuscript here: http://www.dovepress.com/international-journal-of-nanomedicine-journal 